\title{
Bat diversity in oligotrophic forests of southern Borneo
}

\author{
Matthew J. Struebig, Birute M.F. Galdikas and Suatma
}

\begin{abstract}
Knowledge of the conservation status of Bornean bats is biased towards areas considered to support high diversity in the northern Malaysian states. Few surveys have been undertaken in Indonesian Borneo, despite it representing over two thirds of the island's land area. We present the first description of a bat assemblage in Borneo's nutrient poor, or oligotrophic, forests (heath and peat swamp), habitats that have been considered depauperate in wildlife. We surveyed two protected areas in Central Kalimantan using harp traps supplemented by mist nets. We recorded 27 species, 18 of which were captured exclusively by harp traps. The bat assemblage of both sites was dominated by vespertilionids of the subfamily Kerivoulinae. The most abundant species, Kerivoula intermedia, accounted for $45 \%$ of standardized captures in Tanjung Puting National Park. At this site 15 species were represented by $<10$ captures each. Hipposideros ridleyi, Kerivoula lenis, Murina aenea and Murina rozendaali, four rare and threatened species, were recorded for the first time in Indonesia, and Phoniscus atrox, Murina cyclotis and Hipposideros doriae were recorded for the first time in Kalimantan. Estimation of species
\end{abstract}

richness indicated that this inventory was almost complete for understorey, narrow-space, insectivores susceptible to capture in harp traps. It is likely that further surveys targeting open spaces, rivers, forest edges and the canopy will record species of other foraging guilds. The inventory exceeds those from other sites in Kalimantan because previous surveys have not used harp traps. However, it is a depauperate subset of assemblages studied in north Borneo, most likely because these sites are better known and are nearer to caves. Despite this relatively low diversity, our study shows that protected areas in oligotrophic forests provide valuable habitat for some of this island's rarest bat species, and are likely to become more important for bat conservation in light of widespread forest disturbance in Borneo.

Keywords Borneo, Chiroptera, diversity, harp traps, heath forest, Kalimantan, peat swamp forest, Sebangau, Tanjung Puting.

This paper contains supplementary material that can only be found online at http://journals.cambridge.org

\section{Introduction}

Borneo is well known for its high species richness and endemism (MacKinnon et al., 1996; Richards, 1996), but habitat loss on this island is of serious conservation concern (ITTO, 1996). In Kalimantan (Indonesian Borneo) over half of the forests have already been cleared, and those that remain are being rapidly destroyed through encroachment, unsustainable logging practices and fire (Rijksen \& Meijaard, 1999). Despite this, faunal distributions in Kalimantan, and also the rest

Matthew J. Struebig* (Corresponding author) School of Biological Sciences, University of East Anglia, Norwich, NR2 7TJ, UK. E-mail m.struebig@qmul.ac.uk

Birute M.F. Galdikas Orangutan Foundation International, 4201 Wilshire Boulevard, Suite 407, Los Angeles, CA 90010, USA

Suatma University of Palangkaraya, Palangkaraya, Central Kalimantan 73111, Indonesia.

${ }^{\star}$ Current address: School of Biological and Chemical Sciences, Queen Mary, University of London, London, E1 4NS, UK.

Received 6 June 2005. Revision requested 23 September 2005.

Accepted 4 January 2006. of Borneo, are poorly known (Sodhi \& Liow, 2000; Meijaard et al., 2005). Most surveys have focused on charismatic species such as birds or large mammals or have been biased towards rich dipterocarp forests of the lowlands and uplands (Payne \& Francis, 1998).

Peat swamp and swampy heath forests are the major forest formations of Borneo's coastal plains, yet they are probably the least known ecologically and the most heavily exploited (MacKinnon et al., 1996; Phillips, 1998). Although they are well represented within Borneo, they are rare outside South-east Asia, and are categorized as critical/endangered and vulnerable, respectively, in a conservation assessment of ecoregions of the IndoPacific (Wikramanayake et al., 2000). Because the definitions of these forest types are inconsistent and their classification from satellite imagery has been problematic, their total extent over Borneo is not known with certainty. Estimates range from 9.1 to 11.9 million ha of peat swamp forest in Borneo, of which 6.4-9.2 million ha are in Kalimantan (Rieley et al., 1996). Peat swamp forests form when sediments build up behind mangroves as rivers drain towards the coast. They are 
often distributed as a mosaic in an association with heath forests in areas of raised and drier ground, sometimes in transition to richer lowland dipterocarp forests. While their underlying geology and ecology is distinct, the soils of both forest types can be waterlogged, acidic and nutrient-poor. Resulting forest is relatively stunted, often with a low canopy and few large trees (Phillips, 1996). Both are generally less species-rich than other lowland dipterocarp forest types and, because caves are rarely found in such areas, we consider them to support fewer bat species.

Bats are a diverse group and form a valuable component of tropical forests because of their roles in controlling insect populations, seed dispersal and pollination (Hutson et al., 2001). As part of the IndoMalayan region Borneo has exceptional bat diversity (Mickleburgh et al., 1992; Findley, 1993; Hutson et al., 2001) with at least 93 species (Simmons, 2005), representing c. $40 \%$ of Bornean land mammals (Payne \& Francis, 1998). However, the majority of our knowledge of this diversity is from surveys of the Malaysian states of Sabah and Sarawak and Brunei (Payne \& Francis, 1998; Kofron, 2002). Surveys of Kalimantan, which represents over two thirds of the island's land area, have not yet expanded beyond the scope of short field trips predominantly used for specimen collection. As a result, distribution records are often patchy, with the majority being common species that are easily captured with minimal sampling effort. More intensive surveys are needed to sample rarer species so that effective conservation planning for bats can be undertaken (Mickleburgh et al., 1992; Hutson et al., 2001).

One of the primary limitations of existing bat studies in Kalimantan has been the sole reliance on mist nets as a sampling technique. Surveys using harp traps are rare in Indonesia and have even been considered a low priority (Suyanto, 2001). However, the potential for harp traps to capture insectivorous bats in the palaeotropics has only relatively recently been realized (Francis, 1989; Rautenbach et al., 1996). The most common bat families of Old World forests (the Rhinolophidae and Hipposideridae, and vespertilionids in the subfamilies Kerivoulinae and Murininae) may actively detect and avoid mist nets (Francis, 1989) by using the specialized echolocation signals they use to find prey in the cluttered forest vegetation (Neuweiler, 1990; Kingston et al., 1999). Studies elsewhere in Asia show that using harp traps in forest habitats can greatly increase the known bat fauna (Kingston et al., 2003; Struebig et al., 2005).

Given the paucity of bat records and the large extent of peat swamp and heath forests in Kalimantan, we sought to document bat diversity that is typical of these forests. Surveys were undertaken in two protected areas in Central Kalimantan chosen because they are representative of the forests that once extended along the swampy plains inland from the southern coast (Fig. 1). Both sites were the subject of specimen collection projects undertaken by the Museum Zoologicum Bogoriense during 1999-2002 (Saim \& Nanang, unpubl. data). Small (non-volant) mammals were the main animals targeted, but bats were also captured opportunistically with mist nets. We describe assemblage composition from species recorded during an intensive harp trapping programme, together with more limited mist netting in the undisturbed swampy-heath forest of Tanjung Puting National Park. This was supplemented with opportunistic harp-trapping of bats in disturbed peat swamp forest of the Sebangau National Park.

\section{Study areas}

Tanjung Puting National Park was established in 1982 and covers $3,040 \mathrm{~km}^{2}$ of predominantly wetlands with extensive mangroves, nipah dominated swamp, and peat swamp forest. Although the Park has suffered encroachment from human activity and illegal logging (Trent, 1998) small areas of drier forest in the north of the Park are undisturbed. This forest can be described as a heath forest that is swampy in parts. Fieldwork was concentrated in this forest type in a $50 \mathrm{~km}^{2}$ study grid at the Camp Leakey Study Area (Fig. 1) established for primate studies in the 1970s. Common tree species include Shorea sp. (meranti), Lithocarpus sp., Koompassia sp. and Eusideroxylon zwageri (ironwood). Access was from one of two northern tributaries to the Sekonyer River $40 \mathrm{~km}$ east of Pangkalanbun (Fig. 1). For a full description see Galdikas \& Shapiro (1994).

Fieldwork in Sebangau National Park was limited to a rudimentary trail system within a former logging concession (Pt. Setia Alam Jaya; $\left.2^{\circ} 19^{\prime} \mathrm{S}, 113^{\circ} 54^{\prime} \mathrm{E}\right)$ $20 \mathrm{~km}$ south-west of the provincial capital, Palangkaraya. At the time the site was managed as a research forest by the University of Palangkaraya. It has since been included within a National Park established by ministerial decree in October 2004. This site lies in the upper catchment of the Sebangau River and is part of $9,200 \mathrm{~km}^{2}$ of peat swamp forest between the Katingan and Kahayan rivers. Fieldwork was undertaken in disturbed mixed swamp and low-pole forest (described in Morrogh-Bernard et al., 2003) within $7 \mathrm{~km}$ of the forest edge and was accessed using an old timber extraction railway as well as canals and skids used for illegal logging. Principal tree species include Shorea sp. (meranti), Gonystylus bancanus (ramin), Cratoxylon glaucum (gerrongang) and Dactylocladus stenostachys (mentibu). 


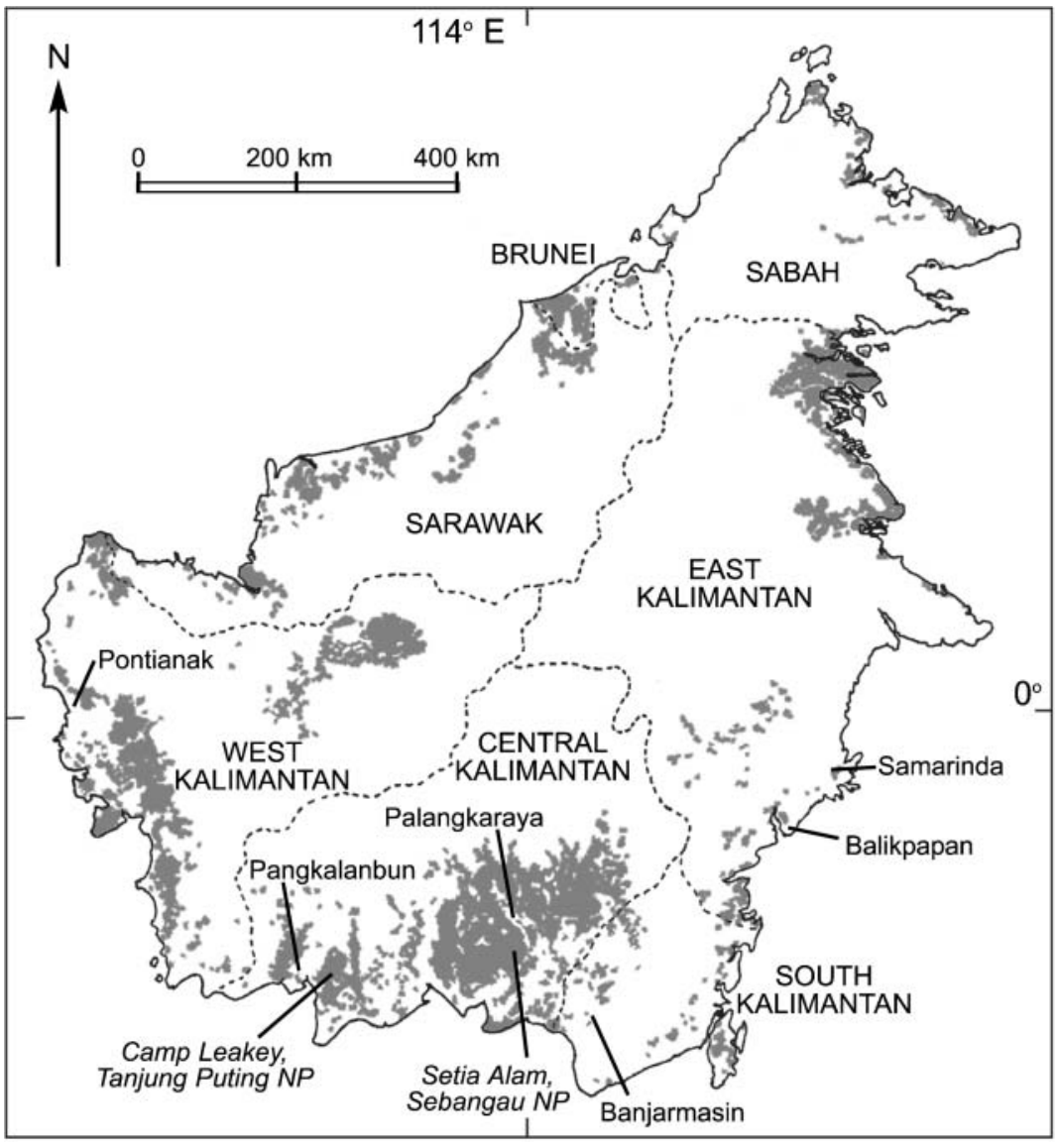

Fig. 1 The extent (in grey) of peat swamp forest in Borneo showing cities and the location of the study areas in Central Kalimantan, Indonesia. Peat swamp forest cover was derived from the combined evaluation of Landsat ETM satellite imagery (1997-2002) and 57 MODIS satellite images acquired in 2001 and 2002 (A. Langner \& F. Siegert, unpubl. data). Heath forest is not shown due to difficulties in classification of this forest type from MODIS images (F. Siegert, pers. comm.) and inconsistencies in other sources. Map produced by Paul Banks.
The climate of southern Central Kalimantan is equatorial with a dry season between May and September. There are no cave systems within $40 \mathrm{~km}$ of either of the survey sites.

\section{Methods}

Between 11 May and 25 July 2004 up to 10 four-bank harp traps (Francis, 1989) were positioned each night, c. 50-100 m apart, across established trails in the heath forest understory of Tanjung Putting National Park. Each trap was set for one night and moved to a new position the following day. Traps were set at dusk, attended every 30 minutes until 20.00 and then left open overnight to be rechecked at dawn following the peaks in bat activity at these times. The total survey effort was 245 harp trap nights encompassing c. $22 \mathrm{~km}$ of trails. In addition, mist nets (6 m long; 70 denier nylon; four shelves; $36 \mathrm{~mm}$ mesh size) were set at ground level across trails or hung vertically in the sub-canopy following Hodgkison et al. (2002). Nets were set in areas believed to maximize capture success (e.g. close to fruiting trees or water sources) and were restricted to the rainforest interior. Netting over rivers and large water bodies in the Park was not possible because accessible sites were near areas known to be used by crocodiles. Ground level nets were set at dusk, attended every 20 minutes and closed at 22.00. Canopy nets were attended throughout the night and closed at dawn. The total net effort was 16 hours for mist nets and 42 hours for canopy nets.

In Sebangau National Park opportunistic bat surveys using harp traps were undertaken as part of a general biodiversity inventory during August 2001 and August 2002. The trapping protocol was the same, but was restricted to 15 trap nights because of the lack of sufficiently large trails for effective trap placement.

Captured bats were temporarily held individually in cloth bags and identified from external characters following Medway (1982), Corbet \& Hill (1992) and Payne \& Francis (1998). Each bat was then weighed, measured, and released at the capture point within 12 hours. The sex, age and reproductive condition of bats were assessed following methods described in Kunz (1988). With the exception of several individuals that died accidentally during the course of the survey, specimens were not collected. For adult individuals, a piece of wing membrane was removed using a $3 \mathrm{~mm}$ 
biopsy punch (Steifel Laboratories, UK) so that recaptures would be recognized. Records of recaptured individuals were excluded from subsequent abundance estimates.

Species accumulation curves and species richness estimators were used to assess the completeness of the Tanjung Puting National Park harp trap inventory. We chose sample-based rather than individual-based curves to account for natural levels of patchiness in the data (Colwell \& Coddington, 1994). Curves were smoothed by randomizing 100 times (analogous to sample-based rarefaction; Colwell \& Coddington, 1994). To account for changes in capture success following periods of rain all bats captured during rain were excluded. Because trapping in the forest understorey may incompletely sample fruit bats, which are known to be more abundant in the sub-canopy (Francis, 1994), we present curves for captures of insectivorous bats and all harp trap captures separately. Because different richness estimators often give different estimates we followed recommendations by O'Hara (2005), and used a range of estimators to develop upper and lower bounds. We used the following species-richness estimators because they have been shown to be robust at adequate sample sizes and sample patchiness (Colwell \& Coddington, 1994; Chazdon et al., 1998): Chao 1 and Chao 2, Jacknife (1st order), abundance coverage (ACE) and incidence coverage (ICE). Estimators were calculated with the programme EstimateS (Colwell, 2004).

\section{Results}

We captured a total of 658 bats (including 60 known recaptures) of 23 species in the heath forest of Tanjung Puting (Table 1, Appendices 1-2). In addition, a number of species were either observed but not captured in the Park (Pteropus vampyrus), were captured at the Park boundary during training events (Macroglossus minimus and Myotis hasseltii) or were present in the mammal collection of the Museum Zoologicum Bogoriense (Megaerops wetmorei). Four species (Balionycteris maculata, four individuals; Cynopterus brachyotis, two individuals; Rhinolophus trifoliatus, two individuals and Emballonura monticola, one individual) were captured in mist nets, and one species (Dyacopterus spadiceus) was recorded from a single capture in a canopy net set beneath an emergent flowering sindur (Sindora sp.) tree. Captures in harp traps accounted for 22 species, 18 of which were captured exclusively by this technique. Five hundred and sixty-eight individuals of 21 species were captured in harp traps when the data was standardized for subsequent analyses. Fifty-one bats (no recaptures) of nine species were captured in harp traps set in the Sebangau peat swamp forest (Table 1). This inventory amounted to 12 species when observations of $P$. vampyrus and extra species in the Museum Zoologicum Bogoriense collection (B. maculata and $M$. wetmorei) were included, and was a subset of that found in Tanjung Puting.

The species accumulation curve based on total harp trap captures in Tanjung Puting reached a value close to an asymptote (Fig. 2) indicating that almost all of the understorey species susceptible to this trapping technique in this area had been captured. When fruit bats (Megachiroptera) were excluded, the value was less, but the shape of the curve was similar, indicating that few species would be added to the inventory if harp trap sampling was extended. Species richness estimators used with total captures predict 21-24 bat species, suggesting that this survey recorded $91-100 \%$ of the understorey bat fauna in Tanjung Puting (Table 2). Estimators predicted $19-22$ species (86-100\% of total) if fruit bats were excluded.

Some species were much more abundant than others (Fig. 3). The bat assemblage was dominated by vespertilionids of the Kerivoulinae subfamily (in Tanjung Puting heath forest seven species representing $73 \%$ of captures). The most abundant species (Kerivoula intermedia) accounted for $45 \%$ of the standardized captures and was represented by 258 individuals. Dominance by this species was similar in the Sebangau peat swamp forest $(46 \%$ of harp trap captures). The next three most abundant species in Tanjung Puting (Kerivoula papillosa, Rhinolophus trifoliatus and R. sedulus) comprised a further $35 \%$ of these captures. Conversely, 15 species were much rarer and were represented by $<10$ captures each.

\section{Discussion}

Our surveys of two sites in Central Kalimantan suggest that Bornean oligotrophic forests support a substantial diversity of bats: 27 species from a combination of survey techniques and observation. Based on captures with harp traps the heath forest in Tanjung Puting National Park sustains at least 23 bat species of 12 genera. Species accumulation curves and richness estimators indicate that the bat inventory for the forest interior of this site is almost complete for forest understorey species susceptible to capture in harp traps. Given our limited sampling using mist and canopy nets, we believe it likely that our inventory is near complete for narrow-space insectivores (as defined by McKenzie et al., 1995, and Schnitzler \& Kalko, 1998). Bats of this foraging guild form a major component of bat diversity in Old World forests and are susceptible to capture in harp traps (Kingston et al., 2003). Our species list for insectivorous bats that forage in forest edges and gaps 
Table 1 Bat species captured in oligotrophic forests of Tanjung Puting and Sebangau National Parks with their foraging strategy, Red List status (IUCN, 2006), and number of individuals captured in the two Parks. Information regarding taxonomic status of species is given in Appendices 1 and 2.

\begin{tabular}{|c|c|c|c|c|}
\hline \multirow[b]{2}{*}{ Species } & \multirow[b]{2}{*}{ Foraging strategy $^{1}$} & \multirow[b]{2}{*}{ Red List status ${ }^{2}$} & \multicolumn{2}{|l|}{ No. captured ${ }^{3}$} \\
\hline & & & Tanjung Puting (heath) & Sebangau (peat swamp) \\
\hline \multicolumn{5}{|l|}{ Pteropodidae } \\
\hline Dyacopterus spadiceus & $\mathrm{Cf}$ & $\mathrm{LR}(\mathrm{nt})$ & 1 & \\
\hline Balionycteris maculata & $\mathrm{Nf}$ & & 15 & $¥$ \\
\hline Cynopterus brachyotis & $\mathrm{Bf}$ & & 8 & $¥$ \\
\hline Megaerops wetmorei & $\mathrm{Bf}$ & & $¥$ & 1 \\
\hline Macroglossus minimus & $\mathrm{Bf}$ & & 1 & \\
\hline \multicolumn{5}{|l|}{ Emballonuridae } \\
\hline Emballonura monticola & $\mathrm{Ei}$ & & 12 & \\
\hline \multicolumn{5}{|l|}{ Megadermatidae } \\
\hline Megaderma spasma & $\mathrm{Ni}$ & & 2 & \\
\hline \multicolumn{5}{|l|}{ Nycteridae } \\
\hline Nycteris tragata & $\mathrm{Ni}$ & & 8 & \\
\hline \multicolumn{5}{|l|}{ Rhinolophidae } \\
\hline Rhinolophus sedulus & $\mathrm{Ni}$ & & 40 & \\
\hline Rhinolophus trifoliatus & $\mathrm{Ni}$ & & 58 & 1 \\
\hline Rhinolophus luctus* & $\mathrm{Ni}$ & & 2 & \\
\hline \multicolumn{5}{|l|}{ Hipposideridae } \\
\hline Hipposideros ridleyi** & $\mathrm{Ni}$ & VU & 5 & \\
\hline Hipposideros doriae* & $\mathrm{Ni}$ & & 1 & \\
\hline \multicolumn{5}{|l|}{ Vespertilionidae } \\
\hline Myotis muricola & $\mathrm{E} / \mathrm{Ni}$ & & 1 & 5 \\
\hline Myotis hasseltii & $\mathrm{Ei}$ & & 1 & \\
\hline Murina suilla & $\mathrm{Ni}$ & & 18 & 3 \\
\hline Murina cyclotis* & $\mathrm{Ni}$ & & 2 & \\
\hline Murina rozendaali** & $\mathrm{Ni}$ & $\mathrm{LR}(\mathrm{nt})$ & 3 & \\
\hline Murina aenea** & $\mathrm{Ni}$ & LR (nt) & 1 & \\
\hline Kerivoula minuta & $\mathrm{Ni}$ & LR (nt) & 10 & 8 \\
\hline Kerivoula intermedia & $\mathrm{Ni}$ & LR (nt) & 276 & 23 \\
\hline Kerivoula papillosa (small)/K.lenis & $\mathrm{Ni}$ & & 7 & \\
\hline Kerivoula papillosa (large) & $\mathrm{Ni}$ & & 54 & 1 \\
\hline Kerivoula hardwickii & $\mathrm{Ni}$ & & 10 & 3 \\
\hline Kerivoula pellucida & $\mathrm{Ni}$ & & 9 & 1 \\
\hline Phoniscus atrox* & $\mathrm{Ni}$ & & 3 & \\
\hline
\end{tabular}

****New records for Kalimantan and Indonesia, respectively; discussed further in Appendix 2.

${ }^{1}$ Foraging strategies were assigned based on studies using cluster analysis of relative wing loading and aspect ratio (Kingston et al., 2003; Hodgkison et al., 2004). Cf, above-canopy frugivore; Bf, below-canopy frugivore, Nf, narrow space (understorey) frugivore/nectarivore; Ei, edge-gap insectivore; $\mathrm{Ni}$, narrow space insectivore.

${ }^{2}$ VU, Vulnerable; LR:nt, Lower Risk: near threatened (IUCN, 2001). We refer to the classification of Hipposideros sabanus for H. doriae, given the taxonomic revisions by Simmons (2005).

$\stackrel{3}{¥}$, Species that were not captured, but whose presence has been confirmed by specimens in the Museum Zoologicum Bogoriense.

and open spaces and for fruit bats is incomplete, as indicated by several species that were recorded outside the study sites and the specimen of Megarops wetmorei in the Museum Zoologicum Bogoriense. Insectivorous species that forage around forest edges and gaps are notoriously difficult to sample because they often forage in areas where harp traps will be ineffective, and some species may avoid mist nets (Kingston et al., 2003). It is also possible that oligotropic forests, with a relatively uneven canopy and more open structure than other lowland forest types, may support more species within this foraging guild. Mist netting over rivers would probably capture additional species, particularly openspace insectivores that forage above the canopy or water courses and may travel long distances from roosts (e.g. Taphozous spp.). Old World fruit bats tend to be more abundant in the forest canopy and sub-canopy (Francis, 1994; Hodgkison et al., 2004), and therefore species may only be sampled at ground level if they are commuting to roosts or are foraging in the understorey. They are also likely to be more abundant during fruiting seasons, and therefore may not have been recorded during our survey. It is therefore likely that additional surveys focusing on the canopy and open spaces of oligotrophic 




Fig. 2 Species accumulation curves for all bat species (solid line) and insectivorous bat species only (dotted line) captured in harp traps set in the forest interior of Camp Leakey, Tanjung Puting National Park.

forests at different times of the year will document additional bat species.

The relative abundance of bat species in Tanjung Puting supports other studies of tropical assemblages that have described a large proportion of rare species and a small number of relatively common species (Francis, 1990; Robinson et al., 2000; Kingston et al., 2003). However, unlike bat assemblages described elsewhere in Indo-Malaya (Francis, 1990; Kingston et al., 2003), this heath forest assemblage is dominated by a single species (Kerivoula intermedia), with the majority of the assemblage consisting of rare species. Our more limited data from the Sebangau peat swamp forest, where $K$. intermedia represented $46 \%$ of all captures, also suggests this dominance. While this may be a result of incomplete or biased sampling, we believe the most plausible explanations to be the lack of cave-roosting fauna in the assemblage and limited roost resources in a stunted forest. The roosting ecology for most Bornean bat species is not known in detail but most are thought to favour either foliage, tree hollows, fallen trees or caves (Payne \& Francis, 1998). We suggest that at sites nearer to caves the structure of a forest bat assemblage will be strongly influenced by the influx of cave-roosting insectivores that are either commuting to roost sites or exploiting the high prey abundance in the forest. There are at least 14 cave-roosting Rhinolophus and Hipposideros species in Borneo, including species such as H. cervinus and $R$. borneensis common in most cave systems surveyed (Payne \& Francis, 1998). Given the absence of these, or any other cave-roosting species at our study sites we believe there are few contenders for the species missing in our inventory. We expect further surveys may record Coelops robinsoni and/or Phoniscus jagorii, two forest-dwelling, but rare, narrow-space insectivorous species that are known from Central Kalimantan (Robinson, 1990; Payne \& Francis, 1998).

The current list of 27 species for Tanjung Puting includes species whose distribution is poorly known, some of which are new records for Indonesia (Appendix 2). Murina aenea, M. rozendaali and Hipposideros ridleyi are rare species, on the IUCN Red List (2006), recorded only from scattered localities in Peninsular Malaysia and north Borneo (Corbet \& Hill, 1992; Payne \& Francis, 1998; Hutson et al., 2001). Kerivoula lenis is a little-known species recorded from India, Peninsular Malaysia and Sabah (Vanitharani et al., 2003). Our discovery of this species in Tanjung Puting is the first record in Indonesia and suggests that it may be more widespread than previously thought.

While the Tanjung Puting bat inventory exceeds those from other sites in Kalimantan, it is a depauperate subset of the better known assemblages in north Borneo. According to Simmons (2005) 93 bat species are recognized in Borneo but if recent museum specimens and records are included (Vanitharani et al., 2003; van Strien, 2004) the total is probably $>98$. Protected areas in oligotrophic forests therefore contribute $27-29 \%$ of Borneo's bat diversity. This is low compared to inventories of protected areas in Sabah and Brunei (Sepilok Forest Reserve, 41 species, Francis, 1990, 1994, Craig, 2003; Kinabalu National Park, 44 species,

Table 2 Expected number of bat species susceptible to capture by harp trap at Camp Leakey, Tanjung Puting National Park, based on species richness estimators used on data standardized to account for differential capture success during rain periods. Decimal fractions were rounded.

\begin{tabular}{|c|c|c|c|c|}
\hline \multirow[b]{2}{*}{ Estimator } & \multicolumn{2}{|c|}{ All bats (21 species) } & \multicolumn{2}{|c|}{ Insectivorous bats only (19 species) } \\
\hline & $\begin{array}{l}\text { Expected species } \\
\text { richness }\end{array}$ & $\begin{array}{l}\text { Inventory } \\
\text { completeness (\%) }\end{array}$ & $\begin{array}{l}\text { Expected species } \\
\text { richness }\end{array}$ & $\begin{array}{l}\text { Inventory } \\
\text { completeness (\%) }\end{array}$ \\
\hline Chao 1 & 21 & 100 & 19 & 100 \\
\hline Chao 2 & 22 & 96 & 20 & 95 \\
\hline Jacknife (1st order) & 24 & 88 & 22 & 86 \\
\hline $\mathrm{ACE}$ & 22 & 96 & 20 & 95 \\
\hline ICE & 23 & 91 & 21 & 91 \\
\hline
\end{tabular}




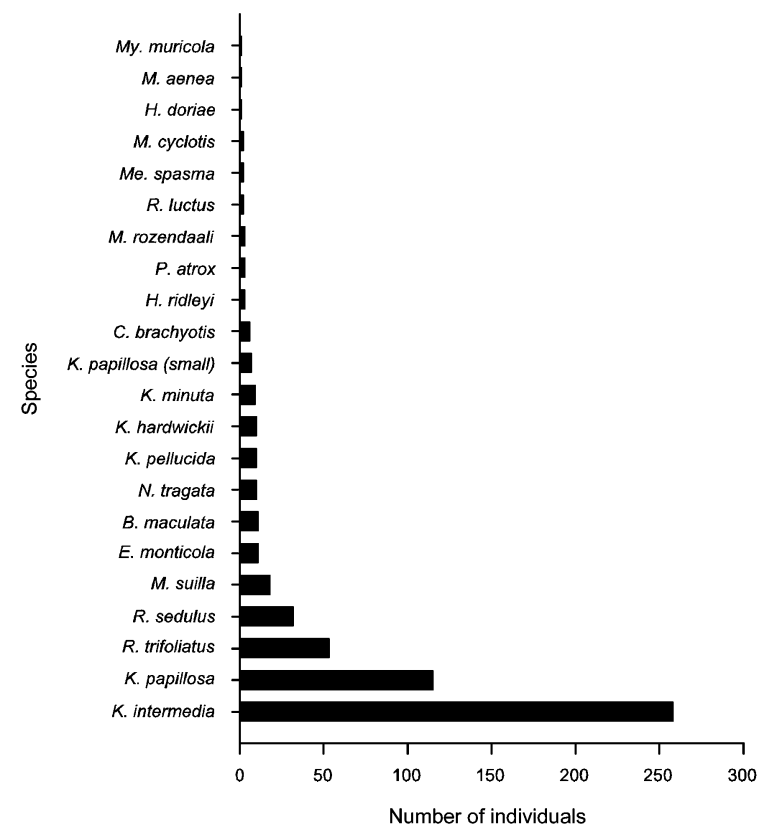

Fig. 3 Relative abundance of bat species captured with harp traps in the forest understorey of Camp Leakey, Tanjung Puting.

B., Balionycteris; C., Cynopterus; E., Emballonura; H., Hipposideros; K., Kerivoula; Me., Megaderma; Mu., Murina; My., Myotis; N., Nycteris; P., Phoniscus; R., Rhinolophus.

Thompson \& Boswell, 2001; Batu Apoi National Park, Brunei, 31 species, Kofron, 2002) but these areas have been the subject of several surveys over a larger spatial scale and include, or are near to, cave systems. Protected areas in Kalimantan have been considered low in bat diversity (e.g. Barito Ulu Research Area, 16 species, McConkey \& Chivers, 2004; Bentuang Karimun National Park, 19 species, Gurmaya, 1999; Kayan Mentarang National Park, 11 species, Mohd. Azlan et al., 2003) but sampling efforts of these areas were limited to opportunistic captures in mist nets or at roosts. As Tanjung Puting has been the subject of an intensive bat survey it is not surprising that the number of species recorded exceeds these areas. However, we credit much of this success to the use of harp traps, because the majority of the species recorded in the Tanjung Puting and Sebangau National Parks (Kerivoulinae and Murininae) are largely absent from other bat inventories in Kalimantan. Previous surveys have overlooked this diversity and it is therefore likely that future surveys with harp traps will increase the number of species recorded. The fact that many of these species are only known from scattered localities (e.g. Kerivoula papillosa, K. pellucida and Hipposideros doriae; Payne \& Francis, 1998) also suggests that harp trapping will show these species to be more widely distributed than was previously expected.
Regardless of their potential distribution many forest bat species are vulnerable to the widespread environmental disturbance occurring in Borneo because of specializations in life history and ecomorphology that restrict their use of open habitats arising from forest loss (reviewed in Kingston et al., 2003). Populations of bat species with more specialized roosting requirements, such as hollows in large fallen trees (e.g. R. sedulus and $H$. ridleyi), are likely to be more limited by the scarcity of these roost types in disturbed forests. While the availability of large trees is naturally limited by the geology of oligotrophic forests, our study shows that if an area is protected from logging and forest fires it may contribute valuable habitat to some of Borneo's rarest bat species. Gumal (2004) also showed the importance of intact peat swamp forest in Sarawak for sustaining viable colonies of flying foxes Pteropus vampyrus. Although Pteropus spp. are still widely reported from the lowlands of Kalimantan much of the peat swamp forest has undergone marked disturbance in recent years (Page et al., 2002). Hunting is also widespread and may have increased following recent forest fires (M Struebig, pers. obs.).

Our study is the first intensive assessment of a bat assemblage in Indonesian Borneo and shows that oligotrophic forests, habitats that have long been considered depauperate in wildlife, actually support a substantial number of rare bat species. Nonetheless, we still know very little about the distribution and conservation status of bats in Kalimantan. Further surveys using harp traps are needed to document bat diversity properly, and our standardized survey data may serve as a benchmark against which assemblages of other sites can be compared. With extensive forest loss throughout Borneo (Rijksen \& Meijaard, 1999), oligotrophic forests have an increasing role to play in the conservation of this island's bat fauna.

\section{Acknowledgements}

We thank the Indonesian Institute of Sciences and the Directorate General for Nature Conservation and Forest Protection, Ministry of Forestry, for granting MS permission to conduct research in Tanjung Puting National Park. Survey work in Sebangau was made possible through an ongoing collaboration between the Universities of Palangkaraya, Indonesia, and Nottingham, UK, for which we thank Suwido Limin and Jack Rieley. Stephen Brend and Ashley Leiman of the Orang-utan Foundation provided logistical support in Tanjung Puting, and Simon Husson, Helen MorroghBernard and Claire McLardy of the Orang-utan Tropical Peatland Project advised in the Sebangau. Susan Page and Florium Siegart provided useful input regarding 
forest cover in Borneo. We are also grateful to Agustinus Suyanto, Curator of Mammals at the Museum Zoologicum Bogoriense, for allowing access to the collection. We thank Alex, Angela Benton-Browne, Ayan, Joanna Cartwright, Rachel Payne, Hetty, Norma, David White and all other staff or volunteers of the Orang-utan Foundation who assisted the project in Tanjung Puting. Tigga Kingston helped with discussions on the survey design and commented on the manuscript, and Paul Bates provided input regarding Kerivoula lenis. This research was funded by personal contributions, and grants awarded for The Kalimantan Bat Conservation Project from the Royal Geographical Society (Institute of Biology and Rio Tinto Inc.), British Ecological Society, University of East Anglia and the Linnaean Society of London (Percy Sladen Memorial Fund).

\section{References}

Abdullah, M.T., Rahman, M.A. \& Hall, L.S. (1997) New records for bats in Sarawak, Malaysia. Malayan Nature Journal, 50, 365-367.

Chazdon, R.L., Colwell, R.K., Denslow, J.S. \& Guariguata, M.R. (1998) Statistical methods for estimating species richness of woody regeneration in primary and secondary rainforests of northeastern Costa Rica. In Forest Biodiversity Research, Monitoring and Modelling (eds F. Dallmeier \& J.A. Comiskey), pp. 285-309. UNESCO \& The Parthenon Publishing Group, Paris, France.

Colwell, R.K. (2004) EstimateS: Statistical Estimation of Species Richness and Shared Species from Samples. Version 7. Http:// purl.oclc.org/estimates [accessed 24 January 2005].

Colwell, R.K. \& Coddington, J.A. (1994) Estimating terrestrial biodiversity through extrapolation. Philosophical Transactions of the Royal Society of London Series B. Biological Sciences, 345, 101-118.

Corbet, G.B. \& Hill, J.E. (1992) The Mammals of the Indomalayan Region: A Systematic Review. Oxford University Press, Oxford, UK.

Craig, L. (2003) A comparative study of bats (Chiroptera) between three forest types: alluvial, sandstone hill, and kerangas, in Sepilok Forest Reserve, Sabah, Malaysia. BSc thesis, University of Aberdeen, UK.

Findley, J.S. (1993) Bats: A Community Perspective. Cambridge University Press, Cambridge, UK.

Francis, C.M. (1989) A comparison of mist nets and two types of harp traps used for capturing bats. Journal of Mammalogy, 70, 865-870.

Francis, C.M. (1990) Trophic structure of bat communities in the understorey of lowland dipterocarp rain forest in Malaysia. Journal of Tropical Ecology, 6, 421-431.

Francis, C.M. (1994) Vertical stratification of fruit bats (Pteropodidae) in lowland dipterocarp rainforest in Malaysia. Journal of Tropical Ecology, 10, 532-550.

Francis, C.M., Kock, D. \& Habersetzer, J. (1999) Sibling species of Hipposideros ridleyi (Mammalia, Chiroptera, Hipposideridae). Senckenbergiana Biologica, 79, 255-270.

Galdikas, B.M.F. \& Shapiro, G. (1994) A Guide Book to Tanjung Puting National Park. Gramedia Press, Jakarta, Indonesia.
Gumal, M.T. (2004) Diurnal home range and roosting trees of a maternity colony of Pteropus vampyrus natunae (Chiroptera: Pteropodidae) in Sedilu, Sarawak. Journal of Tropical Ecology, 20, 247-258.

Gurmaya, K.J., Boeardi, Iskandar, S., Susilo, A. \& Sudradjat, A.R. (1999) Keanekaragaman mammalia di Taman Nasional Bentuang Karimun, Kalimantan Barat [Mammal diversity in Bentuang Karimun National Park, West Kalimantan]. In Rencana pengelolaan Taman Nasional Bentuang Karimun: usaha mengintegrasikan konservasi keanekaragaman hayati dengan pembangunan propinsi Kalbar [Management Plan for TNBK: Integrating Biodiversity Conservation with Provincial Development] (ed. Soedjito), pp. 32-338. WWF Indonesia, PHPA, ITTO, Pontianak, Indonesia.

Hodgkison, R., Ahmad, D., Balding, S.T., Kingston, T., Zubaid, A. \& Kunz, T.H. (2002) Capturing bats (Chiroptera) in tropical forest canopies. In The Global Canopy Programme Handbook: Techniques of Access and Study in the Forest Roof (eds A.W. Mitchell, K. Secoy \& T. Jackson), pp. 160-167. Global Canopy Programme, Oxford, UK.

Hodgkison, R., Balding, S.T., Zubaid, A. \& Kunz, T.H. (2004) Habitat structure, wing morphology, and vertical stratification of Malaysian fruit bats (Megachiroptera: Pteropodidae). Journal of Tropical Ecology, 20, 667-673.

Hutson, A.M., Mickleburgh, S.P. \& Racey, P.A. (2001) Microchiropteran Bats: Global Status Survey and Conservation Action Plan. IUCN/SSC Chiroptera Specialist Group, IUCN, Gland, Switzerland and Cambridge, UK.

ITTO (1996) Annual Review and Assessment of the World Tropical Timber Situation 1995. International Tropical Timber Organization, Yokohama, Japan.

IUCN (2001) 2001 Categories and Criteria (version 3.1). IUCN, Gland, Switzerland [http://www.redlist.org/info/ categories_criteria2001.html, accessed 10 May 2006].

IUCN (2006) 2006 IUCN Red List of Threatened Species. IUCN, Gland, Switzerland [http://www.redlist.org, accessed 10 May 2006].

Kingston, T., Francis, C.M., Zubaid, A. \& Kunz, T.H. (2003) Species richness in an insectivorous bat assemblage from Malaysia. Journal of Tropical Ecology, 19, 67-79.

Kingston, T. \& Hogkison, R. (1994) The Malaysian Fruit Bat Project '94. Unpublished Report to the Royal Geographical Society, London, UK.

Kingston, T., Jones, G., Zubaid, A. \& Kunz, T.H. (1999) Echolocation signal design in Kerivoulinae and Murininae (Chiroptera: Vespertilionidae) from Malaysia. Journal of Zoology, 249, 359-374.

Kofron, C.P. (2002) The bats of Brunei Darussalam, Borneo. Mammalia, 66, 259-274.

Kunz, T.H. (1988) Ecological and Behavioral Methods for the Study of Bats. Smithsonian Institution Press, Washington, DC, USA.

MacKinnon, K., Hatta, G., Halim, H. \& Mangalik, A. (1996) The Ecology of Kalimantan. Periplus Editions, Singapore.

McConkey, K.R. \& Chivers, D.J. (2004) Low mammal and hornbill abundance in the forests of Barito Ulu, Central Kalimantan, Indonesia. Oryx, 38, 439-447.

McKenzie, N.L., Gunnell, A.C., Yani, M. \& Williams, M.R. (1995) Correspondence between flight morphology and foraging ecology in some paleotropical bats. Australian Journal of Zoology, 43, 241-257.

Medway, L. (1982) The Wild Mammals of Malaya (Peninsular Malaysia) and Singapore, 2nd edition. Oxford University Press, Kuala Lumpur, Malaysia. 
Meijaard, E., Sheil, D., Nasi, R., Augeri, D., Rosenbaum, B., Iskandar, D., Setyawati, T., Lammertink, M., Rachmatika, I., Wong, A., Soehartono, T., Stanley, S. \& O'Brien, T. (eds) (2005) Life After Logging: Reconciling Wildlife Conservation and Production Forestry in Indonesian Borneo. Center for International Forestry Research, Bogor, Indonesia.

Mickleburgh, S.P., Hutson, A.M. \& Racey, P.A. (eds) (1992) Old World Fruit Bats - An Action Plan for their Conservation. IUCN/ SSC Chiroptera Specialist Group, IUCN, Gland, Switzerland and Cambridge, UK.

Mohd. Azlan, J., Maryanto, I. \& Kartono, A.P. (2003) Diversity, relative abundance and conservation of chiropterans in Kayan Mentarang National Park, East Kalimantan, Indonesia. In Joint Biodiversity Expedition in Kayan Mentarang National Park (eds A. Mardiastuti \& T. Soehartono), pp. 153-162. Ministry of Forestry, WWF Indonesia/ITTO, Jakarta, Indonesia.

Morrogh-Bernard, H., Husson, S., Page, S.E. \& Rieley, J.O. (2003) Population status of the Bornean orang-utan (Pongo pygmaeus) in the Sebangau peat swamp forest, Central Kalimantan, Indonesia. Biological Conservation, 110, 141-152.

Neuweiler, G. (1990) Auditory adaptations for prey capture in echolocating bats. Physiological Review, 70, 615-641.

O'Hara, R.B. (2005) Species richness estimators: how many species can dance on the head of a pin? Journal of Animal Ecology, 74, 375-386.

Page, S.E., Siegart, F., Rieley, J.O., Boehm, H.-D.V., Adi-Jaya \& Limin, S. (2002) The amount of carbon released from peat and forest fires in Indonesia in 1997. Nature, 420, 61-65.

Payne, J.B. \& Francis, C.M. (1998) A Field Guide to the Mammals of Borneo. The Sabah Society, Kota Kinabalu, Malaysia.

Phillips, V.D. (1998) Peatswamp ecology and sustainable development in Borneo. Biodiversity and Conservation, 7, 651-671.

Rautenbach, I.L., Fenton, M.B. \& Whiting, M.J. (1996) Bats in riverine forest and woodlands: a latitudinal transect in southern Africa. Canadian Journal of Zoology, 74, 312-322.

Richards, P.W. (1996) The Tropical Rainforest, 2nd edition. Cambridge University Press, Cambridge, UK.

Rieley, J.O., Ahmad-Shah, A.A. \& Brady, M.A. (1996) The extent and nature of tropical peat swamps. In Tropical Lowland Peatswamps of Southeast Asia: Proceedings of Workshop on Integrated Planning and Management of Tropical Lowland Peatlands, Cisarua, Indonesia, 3-8 July 1992 (eds E. Maltby, C.P. Immirzi \& R.J. Safford), pp. 17-53. IUCN, Gland, Switzerland.

Rijksen, H.D. \& Meijaard, E. (1999) Our Vanishing Relative: The Status of Wild Orang-utans at the Close of the Twentieth Century. Kluwer Academic Publishers, Dordrecht, Netherlands.

Robinson, M. (1990) Project Barito Ulu chiroptera survey February-April 1989. Bat Research News, 32, 21-23.

Robinson, W.D., Brawn, J.D. \& Robinson, S.K. (2000) Forest bird community structure in central Panama: influence of spatial scale and biogeography. Ecological Monographs, 70, 209-235.

Schnitzler, H.-U. \& Kalko, K.M.V. (1998) How echolocating bats search and find food. In Bat Biology and Conservation (eds T.H. Kunz \& P. Racey), pp. 183-196. Smithsonian Institution Press, Washington, DC, USA.

Simmons, N.B. (2005) Chiroptera. In Mammal Species of the World. A Taxonomic and Geographic Reference (eds D.E. Wilson
\& D.M. Reeder), pp. 312-529. The John Hopkins University Press, Baltimore, USA.

Sodhi, N.S. \& Liow, L.H. (2000) Improving conservation biology research in Southeast Asia. Conservation Biology, 14, 1211.

Struebig, M.J., Rossiter, S.J., Bates, P.J.J., Kingston, T., Oo, S.S.L., Nwe, A.A., Aung, M.M., Win, S.S. \& Mya, K.M. (2005) Results of a recent bat survey of Upper Myanmar including records from the Kachin forests. Acta Chiropterologica, 7, 147-163.

Suyanto, A. (2001) Kelelawar di Indonesia (Bats in Indonesia). Puslitbang Biologi, Indonesian Institute of Sciences (LIPI), Bogor, Indonesia.

Thompson, F. \& Boswell, A. (2001) Bat Survey of Kinabalu National Park. Unpublished Report to the Royal Geographical Society, London, UK.

Trent, S. (ed.) (1998) The Politics of Extinction: The Orang-utan Crisis and the Destruction of Indonesia's Forests. Environmental Investigation Agency, Emmerson Press, London, UK.

Vanitharani, J., Rajendran, A., Bates, P.J.J., Harrison, D.L. \& Pearch, M.J. (2003) A taxonomic reassessment of Kerivoula lenis Thomas, 1916 (Chiroptera : Vespertilionidae) including a first record from peninsular India. Acta Chiropterologica, 5, 49-60.

van Strien, N. (2004) Indoaustralian Mammal Atlas - A Taxonomic and Faunal Reference and Atlas. Netherlands Museum of Natural History, Leiden, The Netherlands.

Wikramanayake, E.D., Dinerstein, E., Loucks, C.J., Olson, D.M., Morrison, J., Lamoreaux, J., McKnight, M. \& Hedao, P. (2000) Terrestrial Ecoregions of the Indo-Pacific: A Conservation Assessment. Island Press, Washington, DC, USA.

\section{Appendices 1-2}

The appendices for this article are available online at http://journals.cambridge.org

\section{Biographical sketches}

Matthew Struebig is currently studying the impacts of forest fragmentation on insectivorous bats in Peninsular Malaysia. Since 2001 he has led surveys and research training in Kalimantan to identify priority areas for bat conservation. His interests in bats and their conservation has also led him to carry out research projects in Sulawesi and Myanmar.

Birute Galdikas has been studying and working to conserve orang-utans and the forests of Tanjung Puting since 1971. She is President of the Orang-utan Foundation International, Professor of Archaeology at Simon Fraser University in Canada and Professor Extraordinaire at the Universitas Nasional in Jakarta, Indonesia.

Suatma is the Head of the Educational Biology Department at the University of Palangkaraya, Indonesia, and has initiated biological surveys in Central Kalimantan to assist the training of undergraduate students. 